This item was submitted to Loughborough's Research Repository by the author.

Items in Figshare are protected by copyright, with all rights reserved, unless otherwise indicated.

\title{
Do cultural differences explain differences in attitudes towards unions? Culture and attitudes towards unions among call centre workers in Britain and India
}

\section{PLEASE CITE THE PUBLISHED VERSION}

http://dx.doi.org/10.1111/irj.12042

\section{PUBLISHER}

(C) John Wiley \& Sons Ltd

\section{VERSION}

AM (Accepted Manuscript)

\section{PUBLISHER STATEMENT}

This work is made available according to the conditions of the Creative Commons Attribution-NonCommercialNoDerivatives 4.0 International (CC BY-NC-ND 4.0) licence. Full details of this licence are available at: https://creativecommons.org/licenses/by-nc-nd/4.0/

\section{LICENCE}

CC BY-NC-ND 4.0

\section{REPOSITORY RECORD}

Sarkar, Santanu, and Andy Charlwood. 2019. "Do Cultural Differences Explain Differences in Attitudes Towards Unions? Culture and Attitudes Towards Unions Among Call Centre Workers in Britain and India". figshare. https://hdl.handle.net/2134/17235. 


\title{
Do cultural differences explain differences in attitudes towards unions? Culture and attitudes towards unions among call-centre workers in the Britain and India
}

\begin{abstract}
This article adds to the literature on worker attitudes towards unions by investigating the impact of cultural attitudes and the call-centre labour process on union attitudes among call centre workers in Britain and India. It is hypothesised that workers with egalitarian and collectivist cultural attitudes will be more likely to have pro-union attitudes than other workers, although if the impact of cultural attitudes is mediated by history and institutions, it might be expected that this relationship is stronger for British than Indian workers. Conversely, if union attitudes are largely a function of the call-centre labour process, we would expect union attitudes to be similar among workers in both countries. Our results only partially support our hypotheses. Collectivist attitudes are only weakly related to union attitudes among the British sample, but are more strongly related in the Indian sample. There are significant differences between union attitudes among our British and Indian samples. The article concludes that relationship between cultural attitudes and union attitudes are heavily dependent on institutional context. Cultural attitudes are unlikely to be either a constraint or a facilitator of union efforts to organise workers.
\end{abstract}

Keywords Attitudes towards unions, call centre, culture, individualism and collectivism, Britain, India. 


\section{Introduction}

Nearly three decades after Gordon et al. (1980) published their research on the antecedents of employee attitudes towards trade unions and against a backdrop of widespread union decline (Blanchflower, 2007) the issue of the determinants of employee attitudes towards unions remains important because employee attitudes towards unions are a key predictor of employee support for unionisation (Charlwood, 2002; Kochan, 1979; Premack and Hunter, 1988; Guest and Dewe, 1988) and therefore are one of several necessary preconditions for union renewal. There is already an extensive literature on the attitudinal and contextual determinants of employees' attitudes toward unions: the perceived costs and benefits of union membership, personality (extraversion and neuroticism), whether or not an employee has a family history of unionisation, previous work experience in a unionised industry, perceived union instrumentality, the type of community an employee lives in and more general political attitudes are all important (Parkes and Razavi, 2004; Summers et al., 1996; Iverson and Kuruvilla, 1995; Deery et al., 1994; Kuruvilla et al., 1993; Barling et al.,1991; Fullagar and Barling, 1989; Gallagher and Clark, 1989; Youngblood et al., 1984; DeCotiis and LeLouran, 1981; Hammer and Berman, 1981; LeLouran, 1980; Schriesheim, 1978). This article aims to build on this literature by testing how broader cultural attitudes relate to attitudes towards unions, specifically whether individualistcollectivist orientations and power distance are related to union attitudes. We do this in the context of call centres in Britain and India.

The specific call centre context is interesting because call centre work is emblematic of the type of globalised service work that has developed over the last 20 years (Holman et al., 2007). It has been posited that the physically isolated and individualised nature of the labour process in call centres is such as to weaken or neutralise the pro-union instincts of workers (Sandhu, 2006; Ramesh, 2004; Noronha and D’Cruz, 2006). The comparative focus of our research also allows us to investigate whether this is the case, or whether union attitudes among call centre workers depend on national institutional context. Methodologically, we do this by administering identical survey instruments, designed to measure culture, work attitudes and union attitudes to samples of British and Indian call centre workers. We then use statistical analysis to compare the relationships between aspects of culture and union attitudes in the two research settings. If 
theories that posit the importance of culture are correct, we would expect to see cultural attitudes having a similar impact in both countries, with cultural attitudes meaning that some workers have more positive union attitudes than others despite the call centre context. By contrast, if theories that posit the importance of the call centre labour process are correct, we would expect to see similarly negative union attitudes in both our British and Indian samples regardless of cultural attitudes. However, if we find support for neither theory, it would suggest that institutional differences between Britain and India explain union attitudes. We find that the relationship between cultural values and the call centre labour process is not as straightforward as theory might lead us to expect. History and institutions matter in determining union attitudes and the relationship between culture and union attitudes.

\section{The Institutions of Employment Relations in Britain and India}

The institutions for the regulation of the employment relationship differ markedly between India and the UK. In India, theoretically at least, the employment relationship is regulated by the Industrial Disputes Act of 1947 and the Trade Unions Act of 1926, which are supposed to ensure protection of workers from unfair labour practices and the right to unionise. However, these laws are widely ignored particularly in the new economy sectors. Britain and India also differ in terms of their general industrial relations climate and systems. British union density was about 25.6\% in 2000 and the union density in India at the same time was little over one per cent (Lawrence and Ishikawa, 2005: 157). Union density in India may be even lower than this because these statistics relate to the formal sectors of the economy, and there is also a very large informal sector, which is not represented in official labour market statistics (Bhattacherjee, 2001: 31). Although union density and membership data in India are "notoriously unreliable” and hard to come by (Bhattacherjee, 2001: 13), the figures presented by different sources indicate a declining trend in union density post liberalization with a sharp fall in the percentage of those unions that submitted annual returns to government (Bhattacherjee, 2001: 22; also see Kuruvilla, Das, Kwon, and Kwon, 2002). In Britain, unions have also experienced significant decline since 1980, with unions losing members and influence as a result of de-industrialization and associated political and economic changes. Despite decline around 26 per cent of employees were union members in 2012 (BIS, 2013). However, the character of unionism has changed, with decline 
among traditionally highly unionized manual workers in the private sector so that professional and white-collar workers in the public sector now constitute the majority of union members.

The two countries differ markedly in organization at the national level. While British unions are organized on industrial and occupational lines, in India unions were traditionally organized on industrial and political lines, which resulted in considerable variation between unions in different Indian states as a result of different regional political traditions. On the one hand city like Mumbai has witnessed evolving business unionism that reflects on linkages between independent plant level unions and growing dominance of private firms on city's economy and on the other hand in Kolkata an exceedingly politicized labour relations regime prevailed until recently with a close nexus between state government and the dominant affiliated federation (see Davala, 1992; Bhattacherjee, 2002).

Economic liberalization during the 1990's saw the weakening of unions in India, with trade unions breaking up ties with political parties (Kuruvilla et al., 2002), a policy which has contributed to an institutional environment that is even less favourable to unions (Gosh, Nandan and Gupta, 2009). Trade union activities in India have traditionally been restricted to large scale industries from old economy sectors like mining, heavy engineering, etc. but even in these sectors, unions have been weakened because they failed to gain a bargaining presence in new workplaces that have developed since the 1990s. Traditional political party-based unions predominant in the older economy have also singularly failed to attract the young well-educated workers from relatively 'high-paid' emerging sectors like ICT and BPO, for whom unions are culturally alien.

In response to the sea change brought by the liberalization, unions began adopting changes in their structures, alliances, actions and policies (see Gosh et al., 2009; Bhattacherjee, 2001: 13). However, in spite of changes in union structure overall union coverage and density remains minimal. There are however some structural similarities in industrial relations in India and the UK. In both countries, collective bargaining tends to operate at the level of the workplace or enterprise. Bargaining is not legally regulated in either country. However, Davala (1992) pointed towards a prevalent bargaining structure in India in which unions in the older industrial sectors organize and bargain on an industry- and/or region-wide basis, whereas the plant/enterprise became the unit of organization and bargaining in the newer industries. 


\section{Union attitudes in the call centre context}

Within these radically different institutional contexts, call centres represent an interesting setting in which to investigate cross-cultural differences in attitudes towards unions. The technology of production means that the experience of employment in call centres, although mediated somewhat by institutional differences between countries, is similar everywhere in the world (Holman et al., 2007, 2009). Further, the growth of business process outsourcing (BPO) often means that British and Indian call centres are operating in the same product markets. However, the Indian call centre industry reproduces the experience of call centre work in exaggerated and culturally-distinctive forms, a labour process that has proved problematical for employers and employees alike (Taylor and Bain, 2005). British and Indian call centres also differ in the education of the workforce and the remuneration associated with the job. In India, call centre work is a graduate occupation with pay to match, while in Britain, call centre work does not require education beyond secondary school level and call centre work is seen as low skilled and low paid. Young Indians from the urban middle class are drawn to call centres, eager to earn enough to have a taste of Western consumerism. The contrast between call centre employment and the wider context of absolute poverty is stark, and is likely to result in different meanings being attached to regular employment than would attached to the same job in a context where extreme poverty is not pervasive (Kahn and Ackers 2004).

It has also been argued that call centres represent an environment that pose a particular challenge to trade unions, because the nature of the call centre labour process undermines and neutralises pro-union attitudes (Sandhu, 2006; Ramesh, 2004; Noronha and D’Cruz, 2006). Consequently, call centres in India are generally not unionised (Taylor and Bain, 2005; Sandhu, 2006; Sarkar, 2009) and there is no works council legislation for the sector. By contrast, in Britain call centres have developed in industries like Banking and Financial Services, Telecommunications and Retail with a history of unionisation, and existing voluntary collective agreements between unions and employers have often been extended to call centres, with the result that many British call centres are unionised. Consequently, a recent study found that $62 \%$ of British call-centres had some form of collective representation, whereas in India no callcentres have collective bargaining coverage (Holman et al., 2007). A comparison of British and Indian call centres allows us to investigate whether call centre workers in both countries share 
similarly, presumably negative, attitudes towards unions, or whether the differing institutions for the regulation of the employment relationship in the two countries result in differing attitudes to unions among workers with a similar labour process.

\section{Culture and attitudes towards unions}

Studies of union attitudes among employees typically hypothesise that union attitudes are a function of employee satisfaction with their job (dissatisfied workers are more likely to have positive attitudes towards unions). General political attitudes (workers with left wing political views are more likely to have positive attitudes towards unions), previous work experience, family background and social context may also play a role, for this reason, studies typically include a full range of controls for personal, job and workplace characteristics. If cultural orientation has played a role in research, it has typically been limited to a moderator role. Following a systematic review of the literature (full details of which are available from the authors on request), we found no studies that look at the role of cultural differences between employees in different countries. This means that the impact of culture on union attitudes is not very well understood, although there is a suggestion that where unions control membership entry and recruit from a single ethnic or racial group the rank and file are more committed (Dubin et al., 1976). There is also some suggestion that employees decide to join unions because of a sense of shared values and beliefs (e.g., Newton and Shore, 1992). In other words, general cultural orientations may play a role in conditioning attitudes towards unions. Indeed, Deery and Walsh (1999) have argued that individualist-collectivist attitudes have an explicit effect on group cohesion, solidarity and class-consciousness.

Here we seek to test the relationship between union attitudes and individualismcollectivism based on the theorization of these concepts developed by Hofstede $(1984,1997)$ and Triandis (1995, 2001). It is the extent to which the individuals in a cultural context value individual or group outcomes, i.e., whether they are individualists or collectivists (Hofstede, 1997). Hofstede (1984) characterized collectivistic cultures as placing priority on family and group and as deriving job satisfaction from conforming to group norms. Collectivism construct has consistently been acknowledged as a powerful indicator of differences among societies (Ronen and Shenkar, 1985; Yang and Bond, 1990). It provides a key dimension in studies of attitudes towards unions (Storey and Bacon, 1993; Deery and Walsh, 1999). By contrast, 
individualist cultures place priority on achieving personal goals and self-actualization. Triandis and Gelfand (1998) extended Hofstede's conception of individualism-collectivism in a way (considering individualism-collectivism as multidimensional rather than uni-dimensional) that we find convincing, by arguing that the interaction between power distance and individualismcollectivism is of central importance to understanding both concepts. The horizontal dimension of power distance captures the extent to which equality is important, while the vertical dimension captures the individual's attitude towards authority and hierarchy. The relationship between power distance and collectivism-individualism is represented in figure one. The central contention of this paper is that Triandis's conceptualization of four types of culture: hierarchical individualism, hierarchical collectivism, egalitarian individualism and egalitarian collectivism will have a bearing on attitudes towards unions, but that this relationship will vary between different national institutional settings.

Insert figure one around here

Of the four cultural types identified in figure one, egalitarian-individualists want to be unique and self-reliant but are uninterested in status. Hierarchical-individualists are achievement orientated and compete for distinction and status. Egalitarian-collectivists perceive themselves as part of a group and emphasize their common goals with others, while hierarchical-collectivists are distinguished by a willingness to sacrifice personal goals for the good of the group and are comfortable with status differentials within the group (Triandis, 2001; Triandis and Suh, 2002).

Extant research suggests that Britain is generally a more individualistic country than India, and that in Britain, in common with other Western European countries people tend to have egalitarian attitudes on measures of power distance (Suh et al., 1998; Schwartz and Ros, 1995). As suggested by research on western cultures (e.g., Haidt et al., 1993), the British tend to endorse autonomy most highly among all spheres of life and egalitarian culture underlies a concern for autonomy and rights (Schwartz, 2007). This accords with sociological analysis of class in Britain, where traditional working class culture is portrayed as being both individualistic and egalitarian (Savage, 2000).There is less empirical evidence on cultural attitudes in India, with the evidence there is tending to focus on students. Verma and Triandis (1999) observed that 
Indian students were more hierarchical and collectivist than U.S. students. However, Sinha and Tripathi (1994) have observed the coexistence of individualism and collectivism in Indian culture. Therefore, to get diverse groups from two cultures, we employed Triandis's conceptualization of four types of culture and based our predictions about union attitudes among British and Indian call-centre employees on their respective classification as egalitarian individualist and hierarchical collectivists.

Conformity to internalized norms (like Windolf and Haas's (1989) concept of value orientation) is often considered a strong motive for joining a union. Gordon et al. (1980) suggested that the primary means of influence on stability of union commitment would seem to be pro-union socialization. Furthermore, Barling et al. (1991) show the importance of early family socialization on union attitudes. This implies that collectivist attitudes formed early in life are likely to result in more pro-union attitudes later in life. There is evidence, which suggests that these traits have fundamental impacts on union attitudes (Iverson and Kuruvilla, 1995; Parkes and Razavi, 2004). Krahn and Lowe (1984) have also suggested that community characteristics, like value systems and social relations, may have an impact on union attitudes. The social bond (which is more commonly evident in collectivistic culture compared to an individualistic culture) might serve as an indirect cause of union commitment (Morrow, 1983). On the other hand, if we go a little further and examine the Individualism-Collectivism construct in an organizational context (see Chatman and Barsade, 1995; Ramamoorthy and Carroll, 1998; Wong and Tjosvold, 2006), there are sufficient evidences of decline of union membership on account of individualism. Lash and Urry (1994) have argued that "cultural individualization has a great influence on the relationship between unions and members”. Studies have found a significant link between individualization of employment relations practices and decline in union membership (see Deery and Walsh, 1999; Storey and Bacon, 1993). Seidman, et al. (1951) reported that management's treatment of the employees as individual employee brings about a change in their union attitudes. Therefore, we might predict that Collectivism and collectivistic orientations will be highly significant in determining union attitudes (Kelly and Kelly, 1994).

In view of the inconsistent literature on India and Britain no separate predictions were made about the direction of effects of each of the egalitarian and hierarchical dimensions of collectivism though such priori predictions were made in case of individualism. Egalitarian individualism is an indicator that an individual has an independent self-concept and values 
uniqueness, and the exercise of independent choice. Independence and opportunity to exercise some control over one's life were frequently cited by employees as major reasons for their favourable union attitudes and membership (Bakke, 1945). This is also an important point in the work of Kornhauser (1965) and Alutto and Belasco (1972). Parkes and Razavi (2004) found that union members reported higher in negative affectivity and more prone to psychological complaints and dissatisfaction with their environment. Agho et al (1992) also observed that employees who are predisposed to experience discomfort are more likely to dislike their jobs relative to employees who are predisposed to be generally happy. So, if dispositional factors are primarily responsible for the consistency of job satisfaction results, then one would see negative affectivity (like experiencing discomfort) causing work situation dissatisfaction thereby resulting in pro-union attitudes. Snyder et al., (1986) have reported that lower levels of competence and low internal control (low internal control is linked to a range of adverse occupational outcomes, including less favourable work performance and motivation, relative to high internal control [see Parkes, 1989]) were present among union members as compared with non-members. This research also chimes with the more recent analysis of Savage (2000) who portrayed trade unions as a vehicle through which the egalitarian and individualistic British working class sought to gain autonomy and control from their employers. Note however that this instrumental approach to trade unionism amongst groups with individualist attitudes is a feature of British and American workers attitudes, who have gained this view of the utility of trade unionism through experience. For Indian call centre workers, without a history of exposure to trade unionism, we might not expect to observe the same relationship. By contrast those with hierarchical attitudes towards power distance are likely to be more generally respectful towards managerial authority and correspondingly less likely have favourable attitudes towards unions. From this analysis we can frame the following hypotheses:

H1. We expect the labour process of call centre work to have a key role in determining union attitudes, therefore, we expect union attitudes to be similar in both our British and Indian samples.

H2. We expect that those call-centre workers with collectivist views to be the most likely to have pro-union attitudes, whereas the unfavourable union attitudes will be greater amongst the individualist call-centre workers. 
H3. We expect those with egalitarian-collectivist views to be the most likely to have pro-union attitudes.

H4. There is also good reason to think that egalitarian-individualists and hierarchical-collectivists will have more pro-union views than hierarchical-individualists.

H5. However, a positive relationship between egalitarian individualism and pro-union views may be a feature of the British sample but not the Indian sample.

\section{Data and Measures}

\section{The Indian sample}

In India, 279 workers participated in the study from three major Business Process Outsourcing (BPO) companies, which varied broadly in terms of business size and service types. At least 90 workers from each call centre participated. Participants were selected at random from within different sections, functions and job grades within the call centers. Data were collected between June and December 2006. The overall response rate was 68 per cent. Of the three companies, the first is a captive call centre (employee strength=10,717) which was ranked among India's top three BPO companies, providing business process management services to Fortune 500 and FTSE 100 companies in Banking and Financial Services, Telecom and Media and Healthcare industries. The second company is a leading BPO service provider (with around 9,500 employees) and its solutions extent across all strata of BPO, technology, and consulting and is applied to organizations in industries as diverse as banking and finance, insurance, retail, telecom and hospitality. The third company is a fully owned subsidiary (employing 850 people) and is a captive call center of one of the leading international financial services company offering personal banking, insurance and pensions products and retail and institutional fund management service.

\section{The British sample}

In the UK, 196 workers participated in the study from one major BPO company and one captive call center. As in the Indian sample, participants were selected at random from within different sections, functions and job grades within the target organizations. The survey data was collected between March and June of 2011. The survey received an overall response rate of 76 percent. 
This rate may be attributable to the timing of the survey distribution to a period when each center was operating at a lower than average working load. The first company is one of the UK's largest BPO service providers employing approximately 3,000 individuals, providing customer contact services to an internet service provider, financial service and retail industries. The second company is a captive call center, employing over 1,200 people, for a leading international banking group that offers personal banking solutions, insurance, mortgaging and business financing options.

\section{Measures}

The Individualism-Collectivism Scale (INDCOL: Triandis, 1995) was used to measure the individual cultural value orientation of horizontal and vertical individualism and collectivism. According to Triandis (1995), INDCOL measures individualism, collectivism and power distance. It consists of 32 items with eight items designed to evaluate each of the four subscales that relate to individualism-collectivism and the egalitarian-hierarchical aspects of power distance. On each of the 32 items, participants indicated their level of agreement on a sevenpoint scale (1=strong disagree; $7=$ strong agree). To test for the goodness of fit of INDCOL to the proposed model, a Confirmatory Factor Analysis (CFA) was undertaken using linear structural relationships (LISREL 8) techniques by the method of maximum likelihood. CFA was used to confirm that the 32 items in our measures of cultural values corresponded to the Triandis (1995) model. All indicators loaded significantly on their respective latent variables for both samples. The results of CFA are reported in table one. The differences in participants' individual cultural values across their demographic and job related characteristics were also assessed (see Table 2). Particularly important are demographic variables like age and gender (Kurman and Sriram, 2002). Bivariate relationships between cultural orientations and job and individual characteristics were also evaluated. In the Indian sample, the roles of age, education, job tenure, type of jobs, work dissatisfaction, and prior union membership were critical in determining value orientations while in British sample the role of gender, job tenure, type of jobs, and call centres in which they were working were important in explaining value orientations. We also evaluated the bivariate relationships between attitudes towards unions and other independent variables. In the Indian sample, the difference in union attitudes across the participants' age $\left(F_{5,273}=11.339, p<0.01\right)$, education $\left(F_{3,275}=29.710, p<0.01\right)$, job tenure $\left(F_{4,274}=46.470, p<0.01\right)$, work dissatisfaction $(F$ 
2, 276 $=3.524, p<0.01)$, low job role $\left(F_{2,276}=65.846, p<0.001\right)$, type of call centre $\left(F_{2,276}=5.261\right.$, $p<0.01$ ), and prior union membership $\left(F_{2,276}=18.305, p<0.001\right)$, were highly significant, while differences in union attitudes across the participants' education $\left(F_{3,192}=2.919, p<0.05\right)$, low job role $\left(F_{2,193}=6.051, p<0.01\right)$, medium job role $\left(F_{2,193}=10.900, p<0.001\right)$, present membership $\left(F_{2,193}=17.894, p<0.001\right)$, and work dissatisfaction $\left(F_{2,193}=1.783, p<0.01\right)$ were highly significant in the British sample. Simply put, education, low job role and work dissatisfaction have played critical roles in explaining attitudes of both British and Indian call centre workers towards unions, while concerning role of membership in determining union attitudes we found the present membership having an influence on attitudes of British respondents and prior membership having an influence on attitudes of Indian respondents. The broad point that emerges from table two is that cultural orientations and attitudes towards trade unions are quite different among our British and Indian samples, as are the relationships between these variables and job and individual characteristics - we will explore this more in our empirical analysis below.

\section{Dependent variable}

In spite of the perceived importance of union attitudes in industrial relations research, union attitudes have not been measured consistently across studies. Through a systematic review of the literature we can identify two empirically distinct constructs: general beliefs about unions and specific beliefs about the actual or likely impact of unions on the respondents own workplace (union instrumentality). In this study attitudes towards union membership are defined as an employee's feeling about any forms of union (adapted from Smith and Hopkins' [1979] conceptualization and measurement of 'attitudes toward union') and the belief in union and in the objectives of organized labour (adapted from Gordon et al 1980). Table three summarises the 9 items which were selected for inclusion in the scale, based on the loadings obtained from factors analysis. The standardized alpha coefficient of reliability and Guttman's coefficient of reproducibility (reported in table one) suggest that two key principles of scalability were adequately fulfilled in selecting these nine items in the scale. Consequently the union attitudes measures were combined into a single scale by summing scores for each individual across nine items and dividing the score by the number of items to which the individual responded. 
Table three around here

\section{Control variables}

A range of individual, job and workplace characteristics were included in our analysis as control variables. These included age, gender, the highest level of educational qualification achieved by the respondent, job title and type of job, job tenure, union membership, and job satisfaction/dissatisfaction. The job satisfaction questions were based on those included within the workplace employment relations survey. Job satisfaction was measured by respondents' responses to seven items measuring the 'importance of different facets of the job' [IJF] and seven items measuring whether the 'job actually provided satisfaction' with these facets [JAP] sub scale) (Smith and Hopkins, 1979: 490). The items are summarized in table five. This provides an intuitively appealing measure of the discrepancy between what an employee wants and what an employee feels s/he is receiving from the job. Factor analysis (reported in table one) suggests that the different items are measuring a single underlying factor. Satisfaction/dissatisfaction scores were calculated by subtracting each employee's score on JAP subscale from his or her score on IJF subscale where a positive score signifies greater endorsement of the construct - work situation dissatisfaction (Smith and Hopkins, 1979: 490).

Tables four around here

Table five around here

\section{Descriptive statistics}

Our British sample had generally been in their jobs longer than the Indian sample. This difference is likely to be an artifact of the recession in Britain - when we conducted our British fieldwork, HR managers reported that labour turnover in their call centres had fallen dramatically since 2007. It is notable that dissatisfaction with work is higher amongst the British sample than the Indian sample - this may be a function of the fact that due to external labour market conditions related to the recession, British workers who were dissatisfied found it harder to find replacement jobs than their Indian counterparts. It may also reflect the composition of the two samples, with the Indian sample comprising a higher proportion of mid and high level jobs. The 
proportions of respondents who were female and in permanent jobs were similar for both samples (65 percent in British and 58 percent in Indian sample were women). The Indian sample were generally educated to a higher level than the British sample: 70 percent of British sample were educated to secondary level with 5 GCSEs or equivalent, compared to just one percent of Indian respondents who only had secondary school level qualifications. Likewise 26 percent of British respondents compared to 64 percent of Indians had an undergraduate level qualification, and four percent of British sample compared to 35 percent of Indian respondents were graduate/masters/with MBA. Seventy seven percent of the British sample compared to 42 percent of the Indian sample was customer service agents (CSA) or equivalent. Consequently, 24 percent of British respondents against 58 percent of Indian respondents were middle-level executives like team leader or manager. Fifty four percent of British respondents against 45 percent of Indian respondents were working in in-house call centres. The proportions of respondents who were working in outsourced call centres were similar for both samples.

\section{Limitations of the data}

Although identical questionnaires were administered to our British and Indian samples, there was a four and half year time lag between the Indian and British fieldwork. During this time period, there were significant changes to the global economic context as a result of the economic crisis of 2007 - 08. Consequently it is possible that some attitudinal differences between the two samples were caused by the different time periods in which data were collected rather than institutional and cultural differences between Britain and India. Note also that previous studies of attitudes towards unions have also included a wider range of determinants of union attitudes than we were able to include in our survey. To include all possible determinants of union attitudes would have resulted in a questionnaire of a length that would have had a significant negative effect on response rates. Consequently, our survey and empirical analysis is designed to test the relationship between specific facets of cultural attitudes and union attitudes while controlling for job and demographic characteristics, but our estimates of the magnitude of the relationship may suffer from omitted variable bias. Therefore our results should not be taken as a precise indicator of the size of relationship between key variables. Finally, the usual disclaimers about crosssectional quantitative analysis apply - we can illuminate statistical relationships between 
variables, but the direction of causality is inferred from the theory set out above, we cannot directly test the direction of causality.

\section{Results}

Let us first begin by comparing some of the key descriptive statistics for the British and Indian samples (reported in table five). British workers reported more favourable attitudes towards unions, although there was also more variation in attitudes amongst the British sample. A higher proportion of Indian workers (82.1 percent [ $n=229]$ ) had no direct experience of unions, having never been union members. The proportion of workers in British sample who were not union members, but who had been in previous jobs was higher than in the Indian sample (26 percent in British sample [ $n=51]$ against 18 percent in Indian sample $[n=50])$. There were no current union members in the Indian sample, while 13 percent of British respondents $(n=25)$ were union members. Overall, these results suggest that our first hypothesis, that union attitudes are largely a result of the call centre labour process, and will therefore be similar in both countries is false. As expected, our British sample had higher scores on our egalitarian individualism scale. Our British sample also had higher scores on the hierarchical-collectivist scale (that is more likely to be in the bottom left and top right quarters of figure one). The scores of our British and Indian samples were similar for the other two dimensions of culture (egalitarian collectivism and hierarchical individualism).

How do our measures of cultural orientation relate to attitudes towards unions? If we examine the correlations between union attitudes and cultural orientation (reported in table five) several points emerge. First, there is no relationship between the collectivist scales and union attitudes (contradicting our second hypothesis). Second, we see that for our British sample, individualists (whether egalitarian or hierarchical) are more likely to have favourable attitudes towards unions. By contrast, for our Indian sample, egalitarian-individualists were less likely to have favourable attitudes towards unions, while hierarchical-individualists were more likely to have favourable union attitudes.

To test the robustness of these results, we estimated a series of ordinary least squares regression models. Table six reports the results of these models. The following discussion relates to the final model with all control variables added. Did the results reported above remain after the influence of job dissatisfaction, union experience and other job and individual characteristics 
were controlled for? In our British sample, egalitarian-individualists were more likely to have favourable attitudes towards unions. In our Indian sample, we observed the opposite result, with egalitarian-individualists less likely to have favourable attitudes towards unions. We also found that hierarchical individualists were more likely to have favourable attitudes towards unions among our Indian sample, as were hierarchical-collectivists. It is then attitudes to authority rather than collectivist attitudes that are the key predictors of attitudes towards unions in India, with those more respectful of authority and more tolerant of social hierarchy having more pro-union attitudes. This is not what our initial theorisation led us to expect. Similarly, there was only a very modest association between hierarchical (vertical) collectivism and pro-union attitudes and no relationship between egalitarian (horizontal) collectivism and union attitudes among our British sample.

Turning to our other results, it is unsurprising that respondents who were union members were more likely to have favourable attitudes towards unions. Former union members had more positive union attitudes among our Indian sample, but not the British sample. The results for job role and whether the respondent had a permanent job at the call centre were also significantly different across our two samples. Job dissatisfaction moderately predicted pro-union attitudes in Britain, but not in India. It is also interesting to note that the model of the determinants of union attitudes for Indian workers explained a much higher proportion of the variance in union attitudes than the equivalent model for British workers (the adjusted $\mathrm{R}^{2}$ of the model with all control variables for our Indian sample is 0.595 compared to just 0.299 for the British sample), which suggests that cultural attitudes are a much more important predictor of union attitudes in India than in Britain.

To sum up, these results suggest little empirical support for our original hypotheses. We hypothesised that union attitudes would be similar in both samples, but our British sample had more pro-union attitudes on average and greater variation in union attitudes. We hypothesized that respondents with more collectivist attitudes would have more pro-union attitudes than those with more individualist views, but they did not, although, there is weak evidence of pro-union attitudes amongst those with hierarchical-collectivist values in both British and Indian samples. We expected those with egalitarian-collectivist values would be the most likely to have prounion attitude but they were not (hypothesis 3). We also hypothesized that respondents with egalitarian-individualist values and hierarchical-collectivist values would be more pro-union 
(hypothesis 4). There was a positive relationship between egalitarian-individualist values and pro-unionism amongst our British sample but not our Indian sample (as predicted by hypothesis 5), but there was no relationship between egalitarian-collectivist values and union attitudes in either sample.

\section{Conclusion}

In this paper, we have sought to test the relationship between an index of cultural values and attitudes towards trade unionism. Based on our reading of the literatures on cultural values and attitudes towards unions, we hypothesized that those with more collectivist values and, in the British case, those with egalitarian-individualist values, would be more likely to have pro-union attitudes and that hierarchical-individualists would have more negative attitudes towards unions. An alternative hypothesis was that the call centre labour process would be a key determinant of union attitudes, with the result that union attitudes would be similar in both countries. We tested these hypotheses among samples of call-centre workers in Britain and India. Our findings suggest that there is no simple or straightforward relationship between cultural values and union attitudes, or between the call centre labour process and union attitudes.

Contrary to expectations, workers with more collectivist values do not have more prounion attitudes. In India, hierarchical-individualists have attitudes towards unions that are more favourable than those of other workers. However, British workers with egalitarian-individualist values did have more pro-union attitudes. This finding is very much in tune with the analysis of Savage (2000), who argued that in the British context, trade unionism and support for trade unionism was an expression of a particularly British working class culture that could be characterized as egalitarian and individualist despite the strongly collective aspects of trade unionism. Although the composition of trade union membership has changed dramatically over the last 30 years, with a white-collar professional union membership now predominating, perhaps this cultural legacy has endured and continues to shape attitudes?

By contrast our results for Indian workers indicate that desire for independence has not converted into a dependency on institutions like union on account of the very different social and economic background. The political economy of India and India's place within the global division of labour has resulted in a call-centre sector that is staffed by young, educated workers, 
and the relative newness of the sector means that there is little experience of trade unionism among call-centre workers, who are carrying out this work in a society with a very high degree of extreme poverty and no welfare state safety net, with the result that the cultural meaning of steady, secure employment and of trade unions is very different in British and Indian contexts.

Thinking through the wider significance of these results for research and practice, note that within the social sciences, research into the effects of culture on worker attitudes and behaviour and research into the effects of institutions of workers attitudes and behaviour have developed largely independently of one another. Our results, point to the need to understand the dynamic interaction of culture and institutions. This would require psychological research into union attitudes to move away from the individualistic, variable orientated approach to research that dominates that literature to consider how to integrate measure of culture and context into research designs (Gall and Fiorito 2012). Comparative research like that reported here is a step in that direction but carefully matched comparative case studies (e.g. Askenazy et al 2012) can also help to uncover the precise mechanisms through which institutions and history shape current attitudes and behaviour.

Overall, our results suggest that because cultural attitudes do not predict union attitudes in a consistent way across our two samples, cultural attitudes are unlikely to be a major constraint (or facilitator) of union efforts to organize workers. To the extent that cultural attitudes matter, they matter within a specific institutional context, not as universal relationships. Therefore a lack of collectivist values and attitudes does not necessarily mean that workers will have negative attitudes towards unions, but nor do collectivist attitudes translate into support for unions. Rather, in both countries, differing degrees of labour commodification and an absence of legal support account for union weakness. If unions are to have a hope of countering these negative trends, they need to create workplace collectivisms that reflect the different institutional, cultural and market contexts in which they find themselves.

\section{References}

Agho, O.A., Mueller, C.W. and Price, J.L. (1992) 'Discriminant validity of measures of job satisfaction, positive affectivity and negative affectivity', Journal of Occupational and Organisational Psychology, 65(3): 185-196. 
Alutto, J. A. and Belasco, J. A. (1972) 'A typology for participation in organizational decision making’, Administrative Science Quarterly, 17(1): 117-125.

Askenazy, P., J-B., Berry, Carré, F., Prunier-Poulmaire, S. \& Tilly, C., (2012) 'Working in large food retailers in France and the USA: The key role of institutions' Work, Employment and Society, 26(4): 588

Bakke, E. W. (1945) ‘Why workers join unions’, Personnel, 22(1): 37-46.

Barling, J., Kelloway, E. K., and Bremermann, E. H. (1991) 'Pre employment predictors of union attitudes: the role of family socialization and work beliefs', Journal of Applied Psychology, 76 (5): 725-31.

Bhattacherjee, D. (2001) 'Organized Labour and Economic Liberalization: Past, Present, and Future, ILO: Geneva: International Institute for Labour Studies.

BIS (2013). Trade Union Membership 2012. London: Department of Business, Innovation and Skills.

Blanchflower, D.G. (2007) 'A cross-country study of union membership', British Journal of Industrial Relations, 45(1): 1-28.

Charlwood, A. (2002) 'Why Do Non-Union Employees Want to Unionize?' British Journal of Industrial Relations, 40 (3): 463 - 92.

Chatman, J. A., and Barsade, S. G. (1995) 'Personality, organizational culture, and cooperation: Evidence from a business simulation’, Administrative Science Quarterly, 40(3): 423-443.

Davala, S. (ed.). (1992) Employment and unionization in Indian industry, New Delhi: FES.

DeCotiis, T. and LeLouran, J. Y. (1981) 'A predictive study of voting behaviour in a representation election using union instrumentality and work perceptions', Organizational Behaviour and Human Performance, 27(1): 103-118.

Deery S. and Walsh, J. (1999) 'The decline of collectivism? A comparative study of white collar employees in Britain and Australia', British Journal of Industrial Relations, 37(2): 245-269.

Deery S., Iverson, R. D., and Erwin, P. J. (1994) 'Predicting organizational and union commitment: the effect of industrial relations climate', British Journal of Industrial Relations, 32(4): 559-75.

Dubin, R., Hedley, R. A, and Taveggia, C. (1976) 'Attachment to work', In R. Dubin (Ed.), Handbook of work, organization, and society (pp. 281-341), Chicago: Rand McNally.

Fullagar, C. and Barling, J. (1989) 'A longitudinal test of the model of the antecedents and consequences of union loyalty’, Journal of Applied Psychology, 74(2): 213-227. 
Gall, G. and Fiorito, J. (2012) 'Union commitment and activism in Britain and the United States: searching for synthesis and synergy in renewal’. British Journal of Industrial Relations. 50(2): $189-213$.

Gallagher, D.G. and Clark, P. F. (1989) 'Research on union commitment: implications for labour’, Labour Studies Journal, 14(3): 52-71.

Ghosh, P., Nandan, S., and Gupta, A. (2009). 'The changing roles of trade unions in India: a case study of National Thermal Power Corporation (NTPC), Unchahar', Asian Academy of Management Journal. 14(1): 37-57.

Gordon, M. E., Philpot, J. W., Burt, R. E., Thompson, C. A., and Spiller, W. E. (1980) 'Commitment to the union: Development of a measure and an examination of its correlates', Journal of Applied Psychology, 65(4): 479-499.

Guest, D. and Dewe, P. (1988) 'Why do workers belong to a trade union? A social psychological study in the UK electronics industry’, British Journal of Industrial Relations, 26(2): 178-193.

Haidt, J., Koller, S., and Dias, M. (1993) 'Affect, culture, and morality, or is it wrong to eat your dog?’ Journal of Personality and Social Psychology, 65(4), 613-628.

Hammer, T. H. and Berman, M. (1981) 'The role of noneconomic factors in faculty union voting', Journal of Applied Psychology, 66(4): 415-421.

Hofstede, G. (1984) Culture's consequences: International differences in work-related values, Beverly Hills, CA: Sage.

Hofstede, G. (1997) Culture and organization: Software of the mind, New York: McGraw-Hill.

Holman, D., Batt, R., and Holtgrewe, U. (2007) 'The global call centre report: international perspectives on management and employment', Report of the Global Call Centre Network, (Global Call Centre Research Network)

Holman, D., Frenkel, S., Sørensen, O., and Wood, S. (2009) 'Work design variation and outcomes in call centers: strategic choice and institutional explanations', Industrial and Labour Relations Review, 62(4); 510-532.

Iverson, R.D. and Kuruvilla, S. (1995) 'Antecedents of union loyalty: the influence of individual dispositions and organizational context’, Journal of Organizational Behaviour, 16(6): 557-582.

Kahn, A. S. and Ackers, P. (2004). 'Neo-pluralism as a theoretical framework for understanding HRM in sub-Saharan Africa.' International Journal of Human Resource Management, 15(7): $1330-1353$.

Kelly, C. and Kelly, J. (1994) 'Who gets involved in collective action? Social psychological determinants of individual participation in trade unions', Human Relations, 47(1): 63-88. 
Kochan, T. A. (1979) 'How American workers view labor unions', Monthly Labor Review, 102(4): 23-31.

Kornhauser, A. (1965) Mental health of industrial worker: A Detroit study, New York: Wiley.

Krahn, H. and Lowe, G.S. (1984) 'Public attitudes towards unions: Some Canadian evidence', Journal of Labour Research, 5(2): 149-164.

Kurman, J. and Sriram, N. (2002) 'Interrelationships among vertical and horizontal collectivism, modesty, and self-enhancement’, Journal of Cross-Cultural Psychology, 33(1): 71-86.

Kuruvilla, S., Das, S., Kwon, H., and Kwon, S. (2002) Trade Union Growth and Decline in Asia. British Journal of Industrial Relations, 40 (3): 431-461.

Kuruvilla, S., Gallagher, D. G., and Wetzel, K. (1993) 'The development of members' attitudes toward their unions: Sweden and Canada', Industrial and Labour Relations Review, 46 (3): 499514.

Lash, S., and Urry, J. (1994) Economies of signs and space, London: Sage.

Lawrence, S., and Ishikawa, J. (2005) 'Social dialogue indicators Trade union membership and collective bargaining coverage: statistical concepts, methods and findings', Working Paper No. 59, ILO Geneva.

LeLouran, J.Y. (1980) 'Predicting union vote from worker attitudes and perceptions', Proceedings of $34^{\text {th }}$ Annual Winter Meetings of the Industrial Relations Research Association, 72-82.

Morrow, P.C. (1983) 'Concept redundancy in organisational research: The case of work Commitment', Academy of Management Review, 8(3): 486-500.

Newton, L. A., and Shore, L. M. (1992) 'A model of union membership: Instrumentality, commitment, and opposition’, Academy of Management Review, 17(2): 275-298.

Noronha, E. and d’Cruz, P. (2006) ‘Organising Call Centre Agents: Emerging Issues’, Economic and Political Weekly, 41(21): 2115-2121.

Parkes, K. R. (1989) 'Personal control in an occupational context'. In A. Steptoe and A. Appels (Eds.), Stress, personal control and health (pp. 26-47). London: Wiley.

Parkes, K. R. and Razavi, T. D. B. (2004) 'Personality and attitudinal variables as predictors of voluntary union membership’, Personality and Individual Differences, 37(2): 333-347.

Premack, S. L. and Hunter, J. E. (1988) 'Individual Unionization Decisions', Psychological Bulletin, 103(2), 223-234.

Ramamoorthy, N., and Carroll, S. (1998) 'Individualism/collectivism orientations and reactions toward alternative human resource management practices’, Human Relations, 51(5): 571-588. 
Ramesh, B.P. (2004) 'Cyber coolies in BPO: insecurities and vulnerabilities of non-standard work’, Economic and Political Weekly, 39(5): 492-497.

Ronen, S. and Shenkar, O. (1985) 'Clustering countries on attitudinal dimensions', Academy of Management Review, 10(3): 435-454.

Sandhu, A. (2006) 'Why unions fail in organising India's BPO-ITES industry', Economic and Political Weekly, 14 (October): 4319-4322.

Sarkar, S. (2009) 'Individualism-collectivism as predictors of BPO employee attitudes toward union membership in India’, Asia Pacific Journal of Management, 26(1): 93-118.

Savage, M. (2000) Class Analysis and Social Transformation, Milton Keynes: Open University Press.

Schriesheim, C.A. (1978) 'Job satisfaction, attitudes towards unions and voting in a union representation election’, Journal of Applied Psychology, 63(5): 548-552.

Schwartz, S. (2007) 'Universalism values and the inclusiveness of our moral universe', Journal of Cross-Cultural Psychology, 38(6), 711-728.

Schwartz, S. and Ros, M. (1995) 'Values in the West: A theoretical and empirical challenge to the Individualism-Collectivism cultural dimension’, World Psychology, 1(2): 99-122.

Seidman, J., London, J., and Karsh, B. (1951) 'Why workers join unions', The Annals of the American Academy of Political and Social Science, 274(1): 75-84.

Sinha, D. and Tripathi, R.C. (1994) 'Individualism in a collectivist culture: A case of coexistence of opposites'. In U. Kim, H.C. Triandis, C. Kagitcibasi, S. Choi, and G. Yoon (eds.), Individualism and collectivism, Thousand Oaks, CA: Sage, pp. 123-138.

Smith, R. L. and Hopkins, A. H. (1979) 'Public employee attitudes toward unions', Industrial and Labour Relations Review, 32(4): 484-499.

Storey, J. and Bacon, N. (1993) 'Individualism and Collectivism: Into the 1990's', International Journal of Human Resource Management, 4 (3): 665-84.

Suh, E., Diener, E., Oishi, S., and Triandis, H. (1998) 'The shifting basis of live satisfaction judgments across cultures: Emotions versus norms', Journal of Personality and Social Psychology, 74(2): 482-493.

Summers, T. P., Betton, J.H., and DeCotiis, T.A. (1996) 'Voting for and against unions: a decision model’, Academy of Management Review, 11(3): 643-655.

Snyder, R. A., Verderber, K., and Morris, J. H. (1986) 'Voluntary union membership of women and men: Differences in personal characteristics, perceptions and attitudes', Journal of Occupational and Organizational Psychology, 59(3): 205-216. 
Taylor, P. and Bain, P. (2005) 'India calling to the far away towns' the call centre labour process and globalization’, Work, Employment and Society, 19 (2): 261-282.

Triandis, H. C. (1995) Individualism and collectivism, Boulder, CO: Westview.

Triandis, H. C. (2001) 'Individualism-collectivism and personality', Journal of Personality, 69(6): 907-924.

Triandis, H. C. and Gelfand, M. J. (1998) 'Converging measurements of horizontal and vertical individualism and collectivism', Journal of Personality and Social Psychology, 74(1): 118-128.

Triandis, H. C. And Suh, E. M. (2002) ‘Cultural influences on personality’, Annual Review of Psychology, 53(February): 133-160.

Verma, J. and Triandis, H.C. (1999) 'The measurement of collectivism in India', In W.J. Lonner, D.L. Dinnel, D.K. Forgays and S.A. Hayes (eds.), Merging past, present and future in crosscultural psychology, Selected papers from the Fourteenth International Congress of the International Association for Cross-Cultural Psychology (pp.256-265), Lisse, The Netherlands: Swets and Zeitlinger.

Windolf, P. and Haas, J. (1989) 'Who joins the union? Determinants of trade union membership in West Germany 1976-1984’, European Sociological Review, 5 (2): 147-165.

Wong, A., and Tjosvold, D. (2006) 'Collectivist values for learning in organizational relationships in China: The role of trust and vertical coordination', Asia Pacific Journal of Management, 23(2): 299-317.

Yang, K. S., and Bond, M. H. (1990) 'Exploring implicit personality theories with indigenous or imported constructs: The Chinese case’, Journal of Personality and Social Psychology, 58(6): 1087-1095.

Youngblood, S. A., DeNisi, A. S., Molleston, J. L., and Mobley, W. H. (1984) 'The Impact of Work Environment, Instrumentality Beliefs, Perceived Labor Union Image, and Subjective Norms on Union Voting Intentions', Academy of Management Journal, 27(3): 576-590. 